\title{
INDOOR RADON IN HOUSES BUILT ON GRAVEL AND SAND DEPOSITS IN SOUTHERN FINLAND
}

\author{
KAISA-LEENA HUTRI and ILONA MÄKELÄINEN
}

\begin{abstract}
KAISA-LEENA HUTRI AND ILONA MÄKELÄINEN 1993. Indoor radon in houses built on gravel and sand deposits in southern Finland. Bull. Geol. Soc. 65, Part 1, 49-58.
\end{abstract}

Studies by the Finnish Centre for Radiation and Nuclear Safety (STUK) have shown that, in Finland, indoor radon concentrations are almost twice as high in houses built on sand or gravel as in houses built on other soil types. The aim of this study was to assess the radon risk on eskers, ice-marginal formations, and other gravel and sand deposits on the basis of factors that can be determined from geological maps.

Altogether, 514 houses built on gravel and sand deposits were selected for the study from the indoor radon database of STUK. Several geological parameters were determined. Empirical statistical models were used to assess the significance of factors affecting indoor radon in glaciofluvial deposits and the sand-dominant littoral deposits occurring in association with them. A relationship was found between increased indoor radon concentrations and the location of a house on a steep-sided esker, in the southeastern rapakivi granite area and on the upper slope or top of an esker. The steepness of the slope also increased the radon concentration in houses on steep-sided eskers. The effect of the topographic features is due to subterranean air-flows. As estimated from the very sparse till sampling, the elevated uranium concentration increased the indoor radon concentration only in houses built on littoral deposits around eskers and ice-marginal formations.

Key words: indoor radon, glaciofluvial deposit, esker, modelling

Kaisa-Leena Hutri and Ilona Mäkeläinen: Finnish Centre for Radiation and Nuclear Safety, P.O. BOX 268, FIN-00101 Helsinki, Finland

\section{INTRODUCTION}

Significant factors affecting the indoor radon concentration are the uranium concentration and permeability of the soil, the foundation type and ventilation of the house (Mäkeläinen et al. 1992) and the "stack effect" driven by differences between the indoor and outdoor temperature (Arvela et al. 1989). Radon (radon-222) is a radioactive rare gas continuously generated in the soil and bedrock through the decay of radium-226. Because the decay series is headed by uranium-238, the uranium concentration of the soil can be expected to correlate with the indoor radon concentration.
Finland, Sweden and certain states of the USA have the highest indoor radon concentrations in the world, and more than half of the radiation dose to the Finnish population comes from radon. With a view to establishing the areas with high indoor radon concentrations, STUK started to draw up radon measurement plans for Finnish municipalities in 1986. The plans are based on data available from soil and bedrock maps and previous radon measurements made in an area (Castrén et al. 1992). Further, to assess the radon risk for future houses, radon prognosis maps have been compiled for areas for which a large number of radon measurements are available (Voutilainen \& 
Mäkeläinen 1991).

Owing to the high permeability of coarse sorted sediments, the indoor radon concentrations of houses built on gravel and sand accumulations in Finland are approximately twice as high as those of houses built on other soil types (Mäkeläinen et al. 1992). These gravel and sand deposits are glaciofluvial deposits and littoral sand layers. However, large differences also occur in indoor radon levels within this group, even in the radon concentrations of the same formation. Since field research is expensive and thus is restricted to small areas only, a method for the preliminary estimation of larger areas is being examined. The aim of this study is to ascertain which of the factors that can be determined on geological maps have an effect on radon level and could therefore be used to estimate the countrywide radon risk in houses built on sand or gravel.

\section{STUDY DESIGN AND METHODS}

\section{Material}

The material is based on the Finnish Centre for Radiation and Nuclear Safety (STUK) database comprising more than 25000 indoor radon measurements with known position coordinates, data on the type of soil and bedrock at the building site, and details about construction of the building; 7000 of these houses were built on sand or gravel. To obtain as accurate information about the building site as possible, we excluded houses in areas for which $1: 20000$-scale soil maps were not available. Most of northern and central Finland was excluded for this reason, as were the areas around the cities of Tampere and Lahti, though there too, very high radon concentrations have been measured in houses built on gravel and sand deposits. In all, 514 houses were selected for the study. The main structural units of the Precambrian in Finland in the study areas and on the map sheets used for the study are shown in Figure 1.

All the indoor radon measurements were conducted with an alpha-track detector in the lowest occupied storey of houses during a two-month period in winter. The radon concentrations measured were corrected to annual means (Arvela \& Winqvist 1989, Castrén et al. 1992). Questionnaires provided the construction data on the houses.

The arithmetic mean of the indoor radon

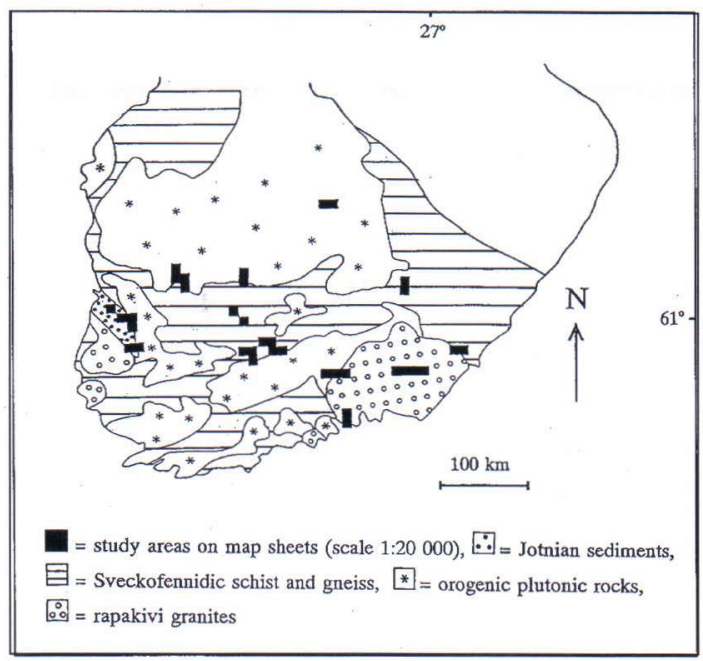

Fig. 1. Study areas and the main structural units of the Precambrian in Finland (simplified from Simonen 1980).

concentrations deduced in this study was $288 \mathrm{~Bq} /$ $\mathrm{m}^{3}$ (standard deviation $563 \mathrm{~Bq} / \mathrm{m}^{3}$ ) and the geometric mean was $168 \mathrm{~Bq} / \mathrm{m}^{3}$ (geometric standard deviation= 2.57). The median was $164 \mathrm{~Bq} / \mathrm{m}^{3}$. Statistics on the type of formation, the location of the house and the main structural unit of the Precambrian in Finland are given in Table 1.

The gravel and sand deposits are not uniformly distributed around the country. The number of houses in the Table 1 shows that, in the Jotnian sedimentary rock area, an area with very few steepsided eskers and no ice-marginal formations at all, there are only two houses on steep-sided eskers. In the southeastern rapakivi granite area there is only one house built on a flat esker. The actual abundance of flat eskers in this area is not known.

\section{Determining the parameters}

It was important that the parameters could be determined with a standard procedure regardless of 
Table 1. Statistics on indoor radon consentration according to the main structural units of the Precambrian of Finland and the soil type formations.

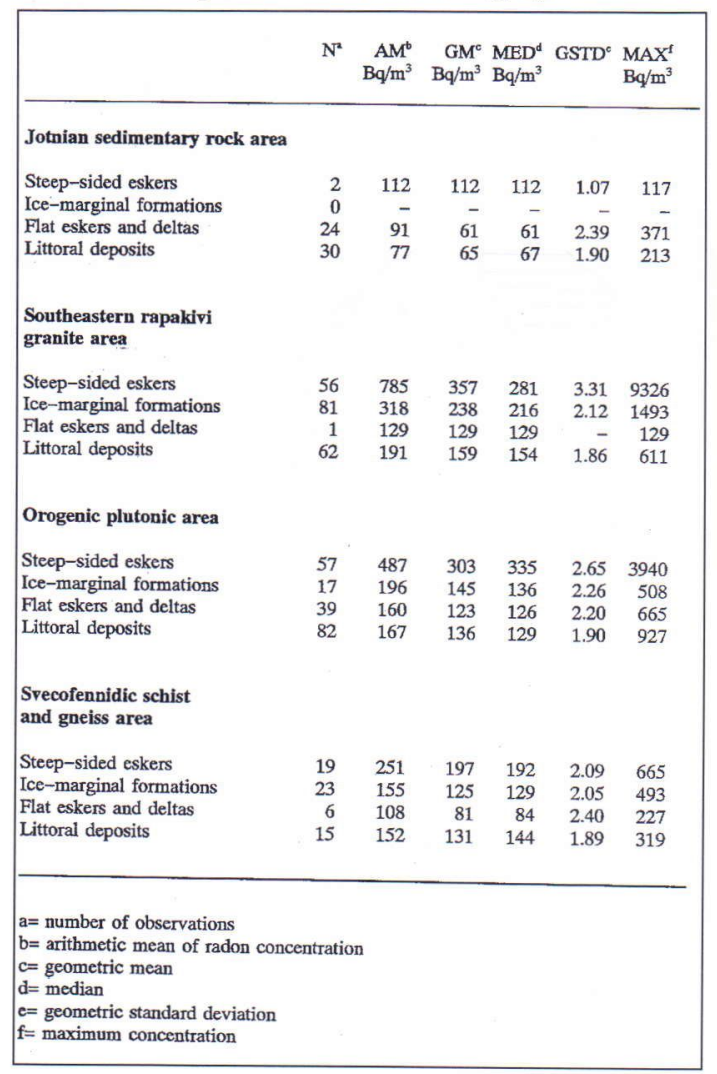

who made the determinations. For details, see the section on determining the parameters in Hutri 1993.

The location and geological features of each building site were checked on $1: 20000$-scale soil maps, and the following parameters were determined: formation type, location of house on the formation (excluding houses on sand deposits), grain size of the soil, steepness of the slope (excluding houses on sand deposits), main structural unit of the Precambrian in Finland, uranium concentration class of the bedrock type and uranium concentration in till.

The glaciofluvial layers are marked on soil maps in violet to distinguish them from the sand-dominant littoral deposits. The soil type layers were tentatively divided on the basis of the map sheet explanations into the following classes: eskers, deltas associated with esker groups, ice-marginal formations and littoral deposits. The eskers were further classified by their top as steep-sided eskers and flat eskers (flat-topped eskers and deep-rooted eskers in Ostrobothnia, see the Atlas of Finland 1992 and Niemelä 1979), because the shape of an esker was considered to demonstrate the difference in structure and grain size distribution of the eskers. Since the tops of flat eskers and deltas have analogous features, they were presumed to behave in the same way in terms of air-flow. The final classification of formation types was as follows: steep-sided eskers, ice-marginal formations, flat eskers and deltas and littoral deposits. Complex eskers with both rising and flat areas were divided into separate units.

Each formation was vertically divided into four units: top, upper part, middle part and lower part. Because only ten houses were located on the top of an esker, these and the houses on the upper part were combined into one unit. The location of the house then had three units: the upper half, the middle part and the lower part. Each of the latter two is a quarter of the formation, see Figure 2.

The soil types were divided into three classes by grain size: 1) gravel (60-2 mm), 2) coarse to medium sand (2-0.2 mm), 3) fine sand to coarse silt (0.2-0.02 mm).

The steepness of the slopes of eskers and icemarginal formations was determined from the difference in the contour line at the house site and the contour line $200 \mathrm{~m}$ downhill from the house; a steepness of 0.1 represents a $20 \mathrm{~m}$ difference in height. Because the contour lines are drawn on 1 : 20000 scale maps with a vertical distance of 5 or $2.5 \mathrm{~m}$ between lines, the steepness is given to within at least 0.0125 .

The study areas were divided into the Jotnian sedimentary rock area, the southeastern rapakivi granite area, an orogenic plutonic rock area and the Svecofennidic schist and gneiss area according to the main structural units of the Precambrian in Finland (Simonen 1980).

For each house, the underlying bedrock type was determined on geological maps ranging in 


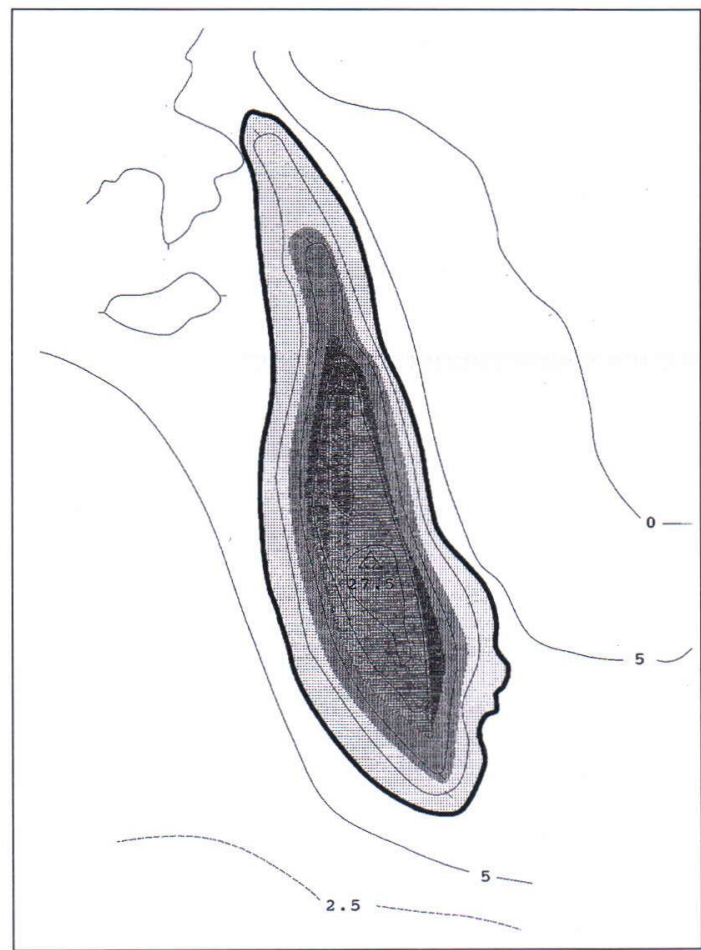

Fig. 2. Location of the house on an esker (outlined in black) Light-coloured screen = on the lower part, medium-coloured screen $=$ the middle part, darkcoloured screen = the upper half. The lines with numbers are contour lines.

scale from $1: 100000$ to $1: 400000$. The rock types were classified into three groups using the information on the mean uranium concentration of till in different bedrock type areas given in The Geochemical Atlas of Finland (1992). The rapakivi granite of southeastern Finland constituted the highest uranium concentration class. The next highest class is formed by granites, gneisses, granodiorites and quartz diorites. Other rock types (sand stone, silica-poor volcanic rocks, diabases, gabbros and amphibolites) were placed in the lowest uranium concentration class.

The uranium concentration of the area was also assessed with reference to the uranium concentration of till given in The Geochemical Atlas of Finland (1992) for the sampling station nearest the house. In that case the location was determined using the coordinates of the house. The average sampling density was one composite sample of five subsamples per $300 \mathrm{~km}^{2}$ (The Geochemical Atlas of Finland 1992).

Air-flow from the ground into a house is affected by the foundation type of a house. According to Arvela et al. (1993a), the use of permeable, lightweight concrete blocks in foundation walls and open stairwells between the basement and ground floor has led to an increase in the radon concentration of houses built during the last fifteen years. To adjust for this effect, the houses were divided into three classes by foundation type and year of construction: houses with a basement built before 1975, houses with a basement built after 1975 and all houses of other foundation types

\section{Statistical analysis}

We used a multiplicative model to calculate the effect of various geological factors on the indoor radon concentration. The foundation type of the house was included in the model as a confounder. The indoor radon concentration $\mathrm{C}$ in a specified dwelling can be described as a product

$$
\mathrm{C}_{\mathrm{ijklmnsu}}=\mathrm{a}_{0} \mathrm{a}_{\mathrm{Fi}} \mathrm{a}_{\mathrm{Sj}} \mathrm{a}_{\mathrm{Tk}} \mathrm{a}_{\mathrm{Ll}} \mathrm{a}_{\mathrm{Gm}} \mathrm{a}_{\mathrm{Un}} \mathrm{b}^{\mathrm{s}} \mathrm{c}^{\mathrm{u}}
$$

where a's refer to the parameters of class variables and $b$ and $c$ to the parameters of continuous variables as follows:

$\mathrm{a}_{0}$ constant term (intercept)

$\mathrm{a}_{\mathrm{Fi}}$ foundation type, $\mathrm{i}=1 \ldots 3$

$\mathrm{a}_{\mathrm{Sj}}$ main structural unit of the Precambrian in Finland, $j=1 \ldots 4$

$\mathrm{a}_{\mathrm{Tk}}$ formation type, $\mathrm{k}=1 \ldots 4$

$\mathrm{a}_{\mathrm{L} 1}$ location of the house on the slope, $1=1$...3

$a_{\text {Gm }}$ grain size, $m=1 \ldots 3$

$a_{U n}$ uranium concentration of bedrock type, $\mathrm{n}=1 \ldots .3$

$b^{s}$ coefficient for the steepness of slope, steepness $\mathrm{s}$ as described above.

$\mathrm{c}^{\mathrm{u}}$ coefficient for mean uranium concentration of till, $\mathrm{u}$ in ppm units

In logarithmic form we obtain: 


$$
\begin{aligned}
\log \left(\mathrm{C}_{\mathrm{ij} \ldots \mathrm{nsu}}\right)= & \log \left(\mathrm{a}_{0}\right)+\log \left(\mathrm{a}_{\mathrm{Fi}}\right)+\log \left(\mathrm{a}_{\mathrm{Sj}}\right)+\log \left(\mathrm{a}_{\mathrm{Tk}}\right)+ \\
& \log \left(\mathrm{a}_{\mathrm{LL}}\right)+\log \left(\mathrm{a}_{\mathrm{Gm}}\right)+\log \left(\mathrm{a}_{\mathrm{Un}}\right)+ \\
& \mathrm{s} \times \log (\mathrm{b})+\mathrm{ux} \log (\mathrm{c})
\end{aligned}
$$

The values of parameter estimates of a's, b and $c$ can be calculated from the parameter estimates of $\log (\mathrm{a}), \log (\mathrm{b})$ and $\log (\mathrm{c})$ of this linear covariance model.

This base model was applied to the data as a whole and stratified in different ways. The model was used to assess the significance of factors and to calculate the parameter estimates of a's, b and c, the expected values of radon and their confidence limits. In the first phase of the analysis the uranium concentration class of the bedrock type, the mean uranium concentration of till and grain size were included in all models. The uranium concentration of the bedrock type was not significant in any of them, and it was excluded from all the more detailed, stratified models. The mean concentration of uranium in till was a significant factor only in the model for littoral deposits, and was included only in this model. Grain size was included only in the models stratified by formation types. Different interaction terms were also tried, but none of them were significant. For comparing pairwise differences, the Schaeffe method was used. Statistical analyses were carried out using the GLM procedure of the SAS program (SAS Institute Inc. 1990).

To compare the main structural units of the Precambrian in Finland,we used model

$$
\mathrm{C}_{\mathrm{ij}}=\mathrm{a}_{0} \mathrm{a}_{\mathrm{Fi}} \mathrm{a}_{\mathrm{Sj}}
$$

For the comparison of formation types in different regions, the data were stratified according to the main structural units. We used three different models. In the Jotnian sedimentary rock area there were only two houses on steep-sided eskers, which we excluded from the model. In this area there are no ice-marginal formations. In the southeastern rapakivi granite area the only house on a delta was excluded. In the orogenic plutonic rock area and schist and gneiss area there were houses on all formation types, and we kept these two units together to study differences between all formation types.

The model used for the Jotnian sedimentary rock area was

$$
\mathrm{C}_{\mathrm{ik}}=\mathrm{a}_{0} \mathrm{a}_{\mathrm{Fi}} \mathrm{a}_{\mathrm{Tk}}, \mathrm{i}=1 \ldots 3, \mathrm{k}=1,2,
$$

for the southeastern rapakivi area

$$
\mathrm{C}_{\mathrm{ik}}=\mathrm{a}_{0} \mathrm{a}_{\mathrm{Fi}} \mathrm{a}_{\mathrm{Tk}}, \mathrm{i}=1 \ldots 3, \mathrm{k}=1 \ldots 3,
$$

and for the orogenic plutonic rock and schist and gneiss areas

$$
\mathrm{C}_{\mathrm{ik}}=\mathrm{a}_{0} \mathrm{a}_{\mathrm{Fi}} \mathrm{a}_{\mathrm{Sj}} \mathrm{a}_{\mathrm{Tk}}, \mathrm{i}=1 \ldots 3, \mathrm{j}=1,2 \mathrm{k}=1 \ldots 4
$$

The same stratification was used to study the effect of topography on glaciofluvial formations. We excluded the houses on littoral deposits from these data. The model for the Jotnian sedimentary rock was

$$
\underset{\mathrm{m}=1 \ldots 3}{\mathrm{C}_{\mathrm{iklms}}}=\mathrm{a}_{0} \mathrm{a}_{\mathrm{Fi}} \mathrm{a}_{\mathrm{Tk}} \mathrm{a}_{\mathrm{Ll}} \mathrm{b}^{\mathrm{s}}, \mathrm{i}=1 \ldots 3, \mathrm{k}=1,2, \mathrm{l}=1 \ldots 3,
$$

for the southeastern rapakivi area

$$
\begin{aligned}
& \mathrm{C}_{\mathrm{iklms}}=\mathrm{a}_{0} \mathrm{a}_{\mathrm{Fi}} \mathrm{a}_{\mathrm{Tk}} \mathrm{a}_{\mathrm{Ll}} \mathrm{b}^{\mathrm{s}}, \mathrm{i}=1 \ldots 3, \mathrm{k}=1 \ldots 3, \mathrm{l}=1 \ldots 3, \\
& \mathrm{~m}=1 \ldots 3
\end{aligned}
$$

and for orogenic plutonic rock and schist and gneiss areas

$$
\begin{aligned}
& \mathrm{C}_{\mathrm{ijklms}}=\mathrm{a}_{0} \mathrm{a}_{\mathrm{Fi}} \mathrm{a}_{\mathrm{Sj}} \mathrm{a}_{\mathrm{Tk}} \mathrm{a}_{\mathrm{Ll}} \mathrm{b}^{\mathrm{s}}, \mathrm{i}=1 \ldots 3, \mathrm{i}=1,2, \mathrm{k}=1 \ldots 4, \\
& \mathrm{l}=1 \ldots 3, \mathrm{~m}=1 \ldots 3
\end{aligned}
$$

To study the effect of topography on different formations (steepness of the slope and location of the house), the data were stratified into three groups: flat eskers and deltas, ice-marginal formations, and steep-sided eskers. The same model (10) was used for all these groups.

$$
\mathrm{C}_{\mathrm{ij} l m s}=\mathrm{a}_{0} \mathrm{a}_{\mathrm{Fi}} \mathrm{a}_{\mathrm{Sj}} \mathrm{a}_{\mathrm{Ll}} \mathrm{a}_{\mathrm{Gm}} \mathrm{b}^{\mathrm{s}}, \mathrm{i}=1 \ldots 3, \mathrm{j}=1 \ldots 4, \mathrm{l}=1 \ldots 3,
$$




$$
\mathrm{m}=1 \ldots 3
$$

For the littoral deposits, we used the model

$$
\mathrm{C}_{\mathrm{ijmu}}=\mathrm{a}_{0} \mathrm{a}_{\mathrm{Fi}} \mathrm{a}_{\mathrm{Sj}} \mathrm{c}^{\mathrm{u}}, \mathrm{i}=1 \ldots . . \mathrm{j}=1 \ldots 4
$$

\section{RESULTS}

The model (3) was used to compare the main structural units of the Precambrian in Finland regardless of other features. According to the pairwise test, indoor radon levels in the southeastern rapakivi granite area are significantly higher and those in the sedimentary rock area lower than in other areas. As to foundation types, radon concentrations are significantly higher in houses with a basement built in 1975 or after than in houses with other foundation types. The foundation type was significant in all models that had any significant factors. The multiple correlation coefficient $\mathrm{R}^{2}$ was $24 \%$.

As to data stratified by main structural units, the data on the Jotnian sedimentary rock area (model (4)) did not show any significant differences between the two formation types in this area: littoral deposits and eskers. No differences were found between foundation types, either. This is partly due to the paucity of observations. According to Table 1, all radon concentrations are below $400 \mathrm{~Bq} / \mathrm{m}^{3}$ (the Finnish national action level for radon concentrations in dwellings).

In contrast, the southeastern rapakivi

Table 3. The orogenic plutonic and Svecofennidic schist and gneiss areas: The expected values and $95 \%$ confidence intervals for indoor radon concentrations. The multiplicative model contains the main structural unit of Precambrian in Finland, the formation type and the foundation type of the house (model 6).
Table 2. The southeastern rapakivi granite area: The expected values and 95\% confidence intervals for indoor radon concentrations. The multiplicative model contains the formation

\begin{tabular}{|c|c|c|c|c|}
\hline Formation type & Foundation type & $\mathbf{G M}^{\mathbf{a}}$ & $\mathbf{L 9 5}^{\mathbf{b}}$ & U95 ${ }^{c}$ \\
\hline Steep-sided esker & $\begin{array}{l}\text { basement, old } \\
\text { basement, new } \\
\text { other types }\end{array}$ & $\begin{array}{l}220 \\
321 \\
467\end{array}$ & $\begin{array}{l}43 \\
53 \\
92\end{array}$ & $\begin{array}{l}1121 \\
1938 \\
2362\end{array}$ \\
\hline $\begin{array}{l}\text { Ice-marginal } \\
\text { formation }\end{array}$ & $\begin{array}{l}\text { basement, old }{ }^{d} \\
\text { basement, new } \\
\text { other types }\end{array}$ & $\begin{array}{l}124 \\
181 \\
264\end{array}$ & $\begin{array}{l}24 \\
30 \\
53\end{array}$ & $\begin{array}{r}635 \\
1095 \\
1325\end{array}$ \\
\hline Littoral deposit & $\begin{array}{l}\text { basement, old }{ }^{d} \\
\text { basement, new } \\
\text { other types }\end{array}$ & $\begin{array}{r}95 \\
139 \\
203\end{array}$ & $\begin{array}{r}19 \\
- \\
40\end{array}$ & $\begin{array}{r}485 \\
- \\
1021\end{array}$ \\
\hline \multicolumn{5}{|c|}{$\begin{array}{l}a=\text { Geometric mean } \\
b=\text { Upper bound of a } 95 \% \text { confidence interval for an individual prediction } \\
c=\text { Lower bound of a } 95 \% \text { confidence interval for an individual prediction } \\
d=\text { Houses with a basement, built before } 1975 \\
e=\text { Houses with a basement, built in } 1975 \text { and after } \\
-=\text { No observations in the class }\end{array}$} \\
\hline
\end{tabular}
type and the foundation type of the house (model 5).

\begin{tabular}{|c|c|c|c|c|c|}
\hline $\begin{array}{l}\text { Main structural } \\
\text { unit }\end{array}$ & $\begin{array}{l}\text { Formation } \\
\text { type }\end{array}$ & $\begin{array}{l}\text { Foundation } \\
\text { type }\end{array}$ & $\mathbf{G M}^{\mathbf{a}}$ & $\mathbf{L} 5^{b}$ & U95 ${ }^{c}$ \\
\hline \multirow[t]{4}{*}{$\begin{array}{l}\text { Orogenic } \\
\text { plutonic area }\end{array}$} & Steep-sided esker & $\begin{array}{l}\text { basement, old }{ }^{d} \\
\text { basement, new } \\
\text { other types }\end{array}$ & $\begin{array}{l}179 \\
389 \\
313\end{array}$ & $\begin{array}{l}40 \\
86 \\
71\end{array}$ & $\begin{array}{r}793 \\
1768 \\
1374\end{array}$ \\
\hline & $\begin{array}{l}\text { Ice-marginal } \\
\text { formation }\end{array}$ & $\begin{array}{l}\text { basement, old }{ }^{d} \\
\text { basement, new } \\
\text { other types. }\end{array}$ & $\begin{array}{r}91 \\
198 \\
159\end{array}$ & $\begin{array}{r}20 \\
43 \\
-36\end{array}$ & $\begin{array}{l}409 \\
911 \\
707\end{array}$ \\
\hline & Flat esker & $\begin{array}{l}\text { basement, old } \\
\text { basement, new } \\
\text { other types }\end{array}$ & $\begin{array}{r}77 \\
167 \\
134\end{array}$ & $\frac{17}{30}$ & $\begin{array}{r}343 \\
594\end{array}$ \\
\hline & Littoral deposit & $\begin{array}{l}\text { basement, old }{ }^{d} \\
\text { basement, new } \\
\text { other types }\end{array}$ & $\begin{array}{r}90 \\
196 \\
158\end{array}$ & $\begin{array}{l}20 \\
43 \\
36\end{array}$ & $\begin{array}{l}398 \\
891 \\
690\end{array}$ \\
\hline \multirow[t]{4}{*}{$\begin{array}{l}\text { Svecofennidic } \\
\text { schist and gneiss } \\
\text { area }\end{array}$} & Steep-sided esker & $\begin{array}{l}\text { basement, old }{ }^{d} \\
\text { basement, new } \\
\text { other types }\end{array}$ & $\begin{array}{l}137 \\
300 \\
241\end{array}$ & $\begin{array}{l}31 \\
65 \\
54\end{array}$ & $\begin{array}{r}616 \\
1394 \\
1066\end{array}$ \\
\hline & $\begin{array}{l}\text { Ice-marginal } \\
\text { formation }\end{array}$ & $\begin{array}{l}\text { basement, old }{ }^{d} \\
\text { basement, new } \\
\text { other types }\end{array}$ & $\begin{array}{r}70 \\
152 \\
122\end{array}$ & $\begin{array}{r}15 \\
- \\
28\end{array}$ & $\begin{array}{r}315 \\
- \\
542\end{array}$ \\
\hline & Flat esker & $\begin{array}{l}\text { basement, old } \\
\text { basement, new } \\
\text { other types }\end{array}$ & $\begin{array}{r}59 \\
129 \\
103\end{array}$ & $\begin{array}{l}- \\
28 \\
23\end{array}$ & $\begin{array}{r}- \\
600 \\
462\end{array}$ \\
\hline & Littoral deposit & $\begin{array}{l}\text { basement, old }{ }^{d} \\
\text { basement, new } \\
\text { other types }\end{array}$ & $\begin{array}{r}69 \\
151 \\
121\end{array}$ & $\begin{array}{l}15 \\
33 \\
27\end{array}$ & $\begin{array}{l}310 \\
695 \\
537\end{array}$ \\
\hline $\begin{array}{l}a=\text { Geometric mea } \\
b=\text { Upper bound } 0 \\
c=\text { Lower bound } \\
d=\text { Houses with } a \\
e=\text { Houses with } a \\
-=\text { No observation }\end{array}$ & $\begin{array}{l}\text { f a } 95 \% \text { confidence } \\
\text { f a } 95 \% \text { confidence } \\
\text { basement, built befo } \\
\text { basement, built in } 1 \\
\text { as it the class }\end{array}$ & $\begin{array}{l}\text { interval for an in } \\
\text { interval for an in } \\
\text { ore } 1975 \\
975 \text { and after }\end{array}$ & $\begin{array}{l}\text { lividual } \\
\text { lividual }\end{array}$ & $\begin{array}{l}\text { oredicti } \\
\text { oredicti }\end{array}$ & \\
\hline
\end{tabular}


area model (5) showed that all three formation types in this area differ significantly from each other. The highest levels are in houses on steep-sided eskers and the lowest in houses on littoral deposits. The radon levels on ice-marginal formations are between these two. The expected values with $95 \%$ confidence levels are shown in Table $2 . \mathrm{R}^{2}$ for the model was $23 \%$.

Model (6) for the orogenic plutonic area and the Svecofennidic schist and gneiss area had a value of $\mathrm{R}^{2} 24 \%$. The expected values with confidence limits are shown in Table 3. As in the southeastern rapakivi granite area, the steep-sided eskers had significantly higher radon levels than other formations, but the parameter estimates for the other three formation types did not differ from each other. When comparing the two bedrock areas, we found that the parameter estimate for the orogenic plutonic rock area was significantly higher than that for the schist and gneiss area.

The models (7), (8) and (9) were used to study the effect of topography of eskers and ice-marginal formations on radon levels stratified by main structural units. No significant factors were found in the Jotnian sedimentary rock area, as in the model (4). In the southeastern rapakivi granite area, the value of $\mathrm{R}^{2}$ was $27 \%$. Significant geological factors were the type of formation, the location of the house on the slope and the steepness of the slope. It turned out that radon concentrations were significantly higher in houses on the upper half of the formation than in those on the lower part. Levels in the middle part were between these two. Moreover, the model (9) for orogenic plutonic and schist and gneiss areas had a higher $\mathrm{R}^{2}, 48 \%$. The significant factors were as in the southeastern rapakivi granite area (main structural unit included), and there was an even greater difference between the two bedrock type areas than in the model (6). The differences between the upper half, and middle and lower parts of the
Table 4. Steep-sided eskers: The expected values and 95\% confidence intervals for houses without a basement and two steepness values. The multiplicative model contains the foundation type, the main structural unit of the Precambrian in Finland and house location as class variables and steepness as a

\begin{tabular}{|c|c|c|c|c|c|}
\hline $\begin{array}{l}\text { Main structural } \\
\text { unit }\end{array}$ & $\begin{array}{l}\text { Steep- } \\
\text { ness }^{2}\end{array}$ & $\begin{array}{l}\text { House } \\
\text { Iocation }\end{array}$ & $\mathbf{G M}^{\mathbf{b}}$ & $\mathrm{L95}^{\mathrm{c}}$ & $\mathrm{U}^{\mathrm{d}} \mathrm{5}^{\mathrm{d}}$ \\
\hline $\begin{array}{l}\text { Southeastern } \\
\text { rapakivi granite } \\
\text { area }\end{array}$ & 0.01 & $\begin{array}{l}\text { lower } \\
\text { middle } \\
\text { upper }\end{array}$ & $\begin{array}{l}283 \\
378 \\
654\end{array}$ & $\begin{array}{r}50 \\
65 \\
113\end{array}$ & $\begin{array}{l}1611 \\
2193 \\
3813\end{array}$ \\
\hline & 0.1 & $\begin{array}{l}\text { lower } \\
\text { middle } \\
\text { upper }\end{array}$ & $\begin{array}{r}597 \\
798 \\
1382\end{array}$ & $\begin{array}{l}106 \\
136 \\
237\end{array}$ & $\begin{array}{l}3360 \\
4684 \\
8064\end{array}$ \\
\hline $\begin{array}{l}\text { Orogenic plutonic } \\
\text { area }\end{array}$ & 0.01 & $\begin{array}{l}\text { lower } \\
\text { middle } \\
\text { upper }\end{array}$ & $\begin{array}{l}187 \\
251 \\
434\end{array}$ & $\begin{array}{l}33 \\
43 \\
75\end{array}$ & $\begin{array}{l}1065 \\
1458 \\
2510\end{array}$ \\
\hline & 0.1 & $\begin{array}{l}\text { lower } \\
\text { middle } \\
\text { upper }\end{array}$ & $\begin{array}{l}396 \\
529 \\
916\end{array}$ & $\begin{array}{r}69 \\
91 \\
159\end{array}$ & $\begin{array}{l}2274 \\
3090 \\
5275\end{array}$ \\
\hline $\begin{array}{l}\text { Svecofennidic } \\
\text { schist and gneiss } \\
\text { area }\end{array}$ & 0.01 & $\begin{array}{l}\text { lower } \\
\text { middle } \\
\text { upper }\end{array}$ & $\begin{array}{l}127 \\
170 \\
295\end{array}$ & $\begin{array}{l}22 \\
29 \\
49\end{array}$ & $\begin{array}{r}744 \\
1008 \\
1766\end{array}$ \\
\hline & 0.1 & $\begin{array}{l}\text { lower } \\
\text { middle } \\
\text { upper }\end{array}$ & $\begin{array}{l}269 \\
360 \\
624\end{array}$ & $\begin{array}{r}46 \\
59 \\
105\end{array}$ & $\begin{array}{l}1570 \\
2186 \\
3689\end{array}$ \\
\hline
\end{tabular}

$a=$ Steepness is the scaled difference between the contour line at the house site and the contour line $\quad 200 \mathrm{~m}$ downhill from the house, a steepness of 0.1 represents a $20-\mathrm{m}$ difference in height.

$\mathrm{b}=$ Geometric mean

$c=$ Upper bound of a 95\% confidence interval for an individual prediction $d=$ Lower bound of a $95 \%$ confidence interval for an individual prediction slope were as in the southeastern rapakivi area.

We studied the effect of topography on different formation types using model (10). The steep-sided esker model had $\mathrm{R}^{2}$ of $38 \%$. Significant geological factors were the main structural unit, the location of the house and the steepness of the slope. The difference between the upper half and lower quarter was significant. The expected values are shown in Table 4. Figure 3 shows the indoor radon concentration as a function of the steepness of the slope on steep-sided eskers.

The same model applied to ice-marginal formations had a slightly lower $\mathrm{R}^{2}, 29 \%$, and it gave the same significant geological factors as the steepsided esker model, except for steepness. The results are shown in Table 5. 
The significant factors for flat eskers and deltas were different: the main structural unit was included in the model, but the second term was grain size. Location and steepness were not significant in the model for flat eskers. Results are given in Table 6. $\mathrm{R}^{2}$ was $36 \%$.

For littoral deposits (model (11)), statistically significant geological factors were the foundation type, the main structural unit and the mean uranium concentration of till in the surrounding 300 $\mathrm{km}^{2}$ area. Figure 4 shows the radon concentration of littoral deposits as a function of the mean uranium concentration of till in the area. The $\mathrm{R}^{2}$ of the model was $28 \%$.

\section{DISCUSSION}

We expected the indoor radon concentration to depend on the uranium concentration of bedrock, but in fact we did not find any such correlation when examining the bedrock type groups in the light of their assumed uranium concentration. On the other hand, since the bedrock types were determined on rock maps at 1:100 000 scale and there is a regional variation in the uranium concentration of bedrock types, in the classification the regional variation within concentration classes is larger than the variation between them.

Still, the differences in indoor radon concentration between the main structural units can mostly be explained by the differences in the uranium concentration of the material. Kivekäs (1973 and 1978) has analysed the uranium concentrations of various bedrock types in Finland. Her investigations suggest that the uranium concentration of rapakivi granite is higher than that of other bedrock types, especially in the eastern study area and that the uranium concentration in the sedimentary rock area is lower than that in other structural units of the Precambrian.

Another explanation is the difference in distribution of the formation types of the main units: The Jotnian sedimentary rock area lacks steep-sided eskers, which are the most radon-prone type. In our study in the rapakivi granite area there was only one house on a delta, which is a less radon-

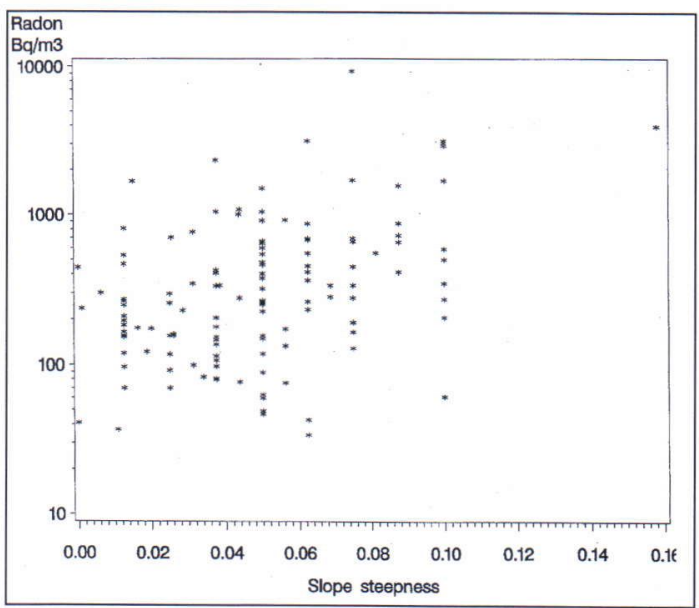

Fig. 3. Indoor radon concentration as a function of slope steepness on steep-sided eskers. Steepness is the scaled difference between the contour line at the house site and the contour line $200 \mathrm{~m}$ downhill from the house; a steepness of 0,1 represents a $20 \mathrm{~m}$ difference in height. 
Table 6. Flat eskers and deltas: The expected values and 95\% confidence intervals for houses without a basement. The multiplicative model contains the foundation type, the main structural unit of the Precambrian in Finland and grain size (model 10).

\begin{tabular}{|c|c|c|c|c|}
\hline $\begin{array}{l}\text { Main structural } \\
\text { unit }\end{array}$ & $\begin{array}{l}\text { Grain } \\
\text { size }\end{array}$ & $\mathbf{G M}^{\mathbf{2}}$ & $\mathbf{L 9 5}^{\mathrm{b}}$ & $\mathbf{U 9 5}^{\mathrm{c}}$ \\
\hline Orogenic plutonic area & $\begin{array}{l}2-60 \mathrm{~mm} \\
0.2-2 \mathrm{~mm} \\
0.02-0.2 \mathrm{~mm}\end{array}$ & $\begin{array}{l}234 \\
131 \\
121\end{array}$ & $\begin{array}{l}51 \\
29 \\
26\end{array}$ & $\begin{array}{r}1086 \\
586 \\
566\end{array}$ \\
\hline $\begin{array}{l}\text { Jotnian sedimentary } \\
\text { rock area }\end{array}$ & $\begin{array}{l}2-60 \mathrm{~mm} \\
0.2-2 \mathrm{~mm} \\
0.02-0.2 \mathrm{~mm}\end{array}$ & $\begin{array}{l}94 \\
53 \\
49\end{array}$ & $\begin{array}{l}20 \\
12 \\
10\end{array}$ & $\begin{array}{l}439 \\
238 \\
229\end{array}$ \\
\hline $\begin{array}{l}\text { Svecofennidic schist } \\
\text { and gneiss area }\end{array}$ & $\begin{array}{l}2-60 \mathrm{~mm} \\
0.2-2 \mathrm{~mm} \\
0.02-0.2 \mathrm{~mm}\end{array}$ & $\begin{array}{r}107 \\
60 \\
56\end{array}$ & $\overline{12}$ & 296 \\
\hline \multicolumn{5}{|c|}{$\begin{array}{l}a=\text { Geometric mean } \\
b=\text { Upper bound of a } 95 \% \text { confidence interval for an individual prediction } \\
c=\text { Lower bound of a } 95 \% \text { confidence interval for an individual prediction } \\
-=\text { No observations in the class }\end{array}$} \\
\hline
\end{tabular}

prone type.

The dominant mechanism responsible for subterranean flows between the upper and lower parts of an esker is the "stack effect" driven by differences in the temperature of the soil air (Okko

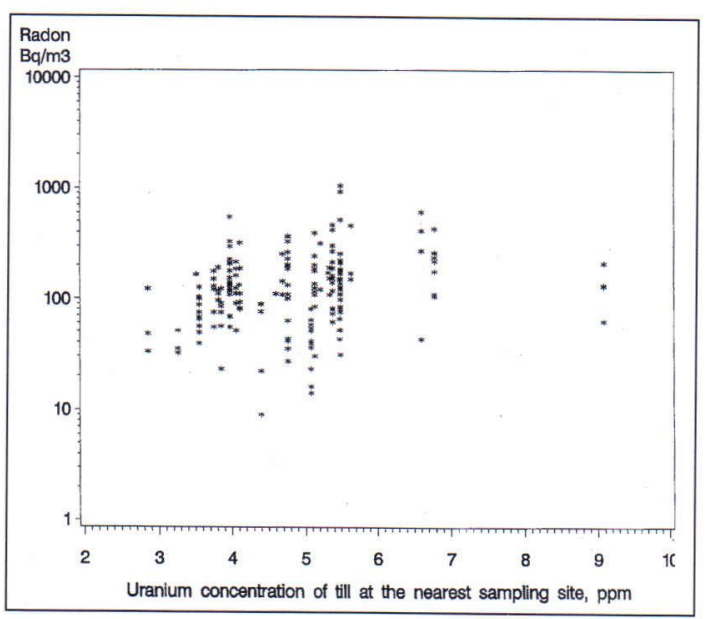

Fig. 4. The indoor radon concentration in houses built on sand deposits as a function of the uranium concentration of till.
1957, Arvela et al. 1988, Arvela et al. 1993b). In winter these air-flows promote radon flows into houses in the upper parts of formations. Seasonal variations were beyond the context of our study, but it is known that the winter concentrations dominate the annual average.

This phenomenon explains many of our results, for example, the higher concentrations on the upper parts of a slope. Janssen et al. (1991) studied the effect of topographic factors on indoor radon levels in Pennsylvania, and found that houses located on uplands had $40 \%$ to $60 \%$ higher radon levels than those on lowlands.

The steep-sided eskers turned out to be the most radon prone formations. Subterranean air-flows can develop well inside steep-sided eskers. The steep-sided eskers are quite narrow, about 400-600 m. The steepness of the slope at the house site describes both the height from the bottom up to the house site and, to some extent, the height of the formation.

Highly permeable gravel also occurs in icemarginal formations, and subterranean air-flows may develop in parts of a formation. In the rapakivi area, the radon concentrations in houses built on ice-marginal formations were significantly higher than in those on littoral deposits, but this could not be seen in the schist and gneiss and orogenic plutonic areas. However, this may not be typical of these areas: in another study (Voutilainen and Mäkeläinen 1993) very high indoor radon concentrations were found in the orogenic plutonic rock area in houses built on an ice-marginal formation (Salpausselkä I) in the city of Lahti.

The flat eskers were the least radon prone of the formations, radon concentrations being almost the same as on littoral deposits. Because of the small height difference, subterranean air-flows inside flat eskers are much weaker than those in steeper formations. In the absence of air-flows the effect of permeability was evident: The coarser the grain size, the higher the permeability, and the higher the 
radon concentrations.

The uranium concentration of till is significant only for littoral deposits. This is due to the fact that their material derives from both glaciofluvial and till formations. The uranium concentration of till can be considered to reflect the uranium concentration of fines including littoral deposits, regionally. The correlation between indoor radon and uranium concentration might be higher if local sand and gravel samples could be used instead of till

\section{REFERENCES}

Arvela, H., Mäkeläinen, I. \& Castrén, O., 1993a. Otantatutkimus asuntojen radonista Suomessa. Summary, Residential Radon Survey in Finland. The Finnish Centre for Radiation and Nuclear Safety, STUKA108, 49 pp.

Arvela, H., Voutilainen, A., Honkamaa,T. \& Rosenberg, A., 1993b. High Indoor Radon Variations and the Thermal Behaviour of Eskers. Submitted for publication for Health Physics.

Arvela, H., Voutilainen, A., Mäkeläinen, I., Castrén, $O$. \& Winqvist, K., 1988. Comparison of predicted and measured variations of indoor radon concentration. Radiation Protection Dosimetry 24, 231-235.

Arvela, H. \& Winqvist K., 1989. A model for indoor radon variations. Environmental International 15, 239246.

Atlas of Finland, Appendix 123-126, Geology, 1992. The National Board of Survey and the Geographical Society of Finland.

Castrén, O., Arvela, H., Mäkeläinen, I. \& Voutilainen, A., 1992. Indoor radon survey in Finland: Methodology and applications. Radiation Protection Dosimetry 45, 413-418.

Hutri, K., 1993. Huoneilman radon glasifluviaalisilla muodostumilla ja radonpitoisuuden ennustamiseen soveltuva menetelmä. Ph.Lic.-theses. Summary: Indoor radon in glaciofluvial formations and method for radon prediction. The University of Helsinki, Department of Geology and Paleontology. 92 pp.

Janssen, I, Stebbings, J.H., Essling, M.A. \& Dimono, K.M., 1991. Prediction of ${ }^{222} \mathrm{Rn}$ from topography in Pennsylvania, Health Physics 61, 775-783.

Kivekäs, L., 1973. Maankuoren radioaktiivisuudesta ja gammasäteilyn laboratoriomittauksista. In M.Ketola (ed.): Petrofysiikka 5-3, 1-26. The Technical Univer- samples.

\section{CONCLUSIONS}

The risk factors for elevated indoor radon concentrations are the location of a house on the top or upper slope of a steep-sided esker and the location of the house in the southeastern rapakivi granite area.

sity of Helsinki.

Kivekäs, L., 1978. Prospecting for geothermal energy in Finland. Nordic symposium on geothermal energy. Charlmers University of Technology and University of Göteborg, 112-119.

Koljonen, T. (ed.), 1992. The Geochemical Atlas of Finland, part 2: till. Geological Survey of Finland.

Mäkeläinen, I., Voutilainen, A. \& Castrén, O., 1992. Prediction of indoor radon concentration based on residence location and construction. In Fredrik T. Cross (ed.): Twenty-Ninth Hanford Symposium on Health and Environment: Indoor Radon and Lung Cancer: Reality or Myth? Battelle Press, Richland. 55-63.

Niemelä, J., 1978. Suomen sora- ja hiekkavarojen arviointiprojekti 1971-78. Summary: The gravel and sand resources of Finland; an inventory project 1971-78. Geological Survey of Finland, Report of investigation 42.

Okko, V., 1957. On the thermal behaviour of some Finnish eskers. Fennia 81, 3-38.

Sas Institute, Inc. 1990. SAS/STAT ${ }^{\circledR}$ User's Guide, Version 6. SAS Institute Inc., Cary, NC.

Simonen, A., 1980. The Precambrian in Finland. Geological Survey of Finland Buletin 304, 58pp.

Voutilainen, A. \& Mäkeläinen, I., 1991. The use of indoor radon measurements and geological data in assessing the radon risk of soil and rock in construction sites in Tampere. The 1991 International Symposium on Radon and Radon Reduction Technology, Vol. 2 Preprints, Philadelphia, Pennsylvania.

Voutilainen, A. \& Mäkeläinen, I., 1993. Use of indoor radon measurements and geological data for radon prognosis in the Lahti area. The 6th International Conference on Indoor Air Quality, Vol. 4 Proceedings, Helsinki, Finland. 